\title{
Proximate and calcium analysis of nixtamalized corn grits as a raw material of Gorontalo traditional meal, Indonesia
}

\author{
SUNARTO KADIR ${ }^{1, \boldsymbol{\bullet}}$, LISNA AHMAD ${ }^{2}$, YOYANDA BAIT ${ }^{2}$ \\ ${ }^{1}$ Department of Public Health, Faculty of Sports and Health, Universitas Negeri Gorontalo. Jl. Jenderal Sudirman No.6, Gorontalo City 96128, Gorontalo, \\ Indonesia. Tel.: +62 853-9862-5876, `email: sunartokadir.17@gmail.com \\ ${ }^{2}$ Department of Food Science and Technology, Faculty of Agriculture, Universitas Negeri Gorontalo. Jl. Jenderal Jenderal Sudirman No.6, Gorontalo \\ City 96128, Gorontalo, Indonesia
}

Manuscript received: 26 July 2018. Revision accepted: 28 February 2019.

\begin{abstract}
Kadir S, Ahmad L, Bait Y. 2019. Proximate and calcium analysis of nixtamalized corn grits as a raw material of Gorontalo traditional meal, Indonesia. Nusantara Bioscience 11: 56-62. This study aims to find out the influence of additional lime concentration and the length of boiling time toward the proximate and calcium grits of corn (Zea mays L). The study was conducted using a randomized group factorial design of two factors. The first factor is calcium concentration consisted of three treatments; $0.5 \%, 1 \%$, and $1.5 \%$, and the second factor is the length of boiling time, consisting of two treatments; the 60-minute boiling time, and the 30-minute boiling time. The parameters of this study were water content, ash content, fat content, protein content, carbohydrate content, and calcium content. The ANOVA analysis reveals that the treatment of calcium concentration, and the length of boiling time insignificantly influence the water content, ash, protein, fat, carbohydrate, and calcium contents of nixtamal corn grits . Grits of nixtamal corn produced in this study has water content of $10.54-11.33 \%$, ash content of $1.34-1.39 \%$, protein content of $9.11-9.40 \%$, fat content of $3.36-3.59 \%$, carbohydrate content of $74.44-75.36 \%$, and calcium content of $10.15-10.92 \%$.
\end{abstract}

Keywords: ANOVA, calcium, corn grits, Gorontalo, nixtamal

\section{INTRODUCTION}

Nixtamalization is one of the methods that has been widely developed. Santiago-Ramos et al. $\left(2018^{\mathrm{a}}\right)$ state that the initial concept of nixtamalization is a thermal process used to cook corn grains in water-alkaline or aqueous solutions as sources of calcium whose main purpose is to soften the pericarp and endosperm so as to facilitate milling. In the same article, Bressani (2009) notes that the importance of nixtamalization for human's nutrition is undeniable since it increases the availability of niacin, lysine, and tryptophan as well as the calcium content, which has contributed to preventing pellagra, rickets, and osteoporosis in some American societies. According to Valderrama-Bravo et al. (2010), the nixtamalization process comprises the cooking of corn kernels in oversaturated calcium hydroxide solution $(1-5 \% \mathrm{w} / \mathrm{w}$ based on corn weight), then, the corn is steeped from 8 to 24 hours and washed to remove excess of lime, pericarp and any solids. The nixtamal (alkaline cooked corn, steeped and washed) is stone ground into a dough, which is used to produce tortillas, tamales, atole, snacks (nachos), instant corn flours, etc.

Food diversification efforts do not support the fluctuation of corn production. Corn production is still limited to export purposes, while the field of corn processing into various products has not received special attention from the community and government. Food diversification activities can increase the uniformity of processed corn products and the economic value of the community. One of the corn processed products often consumed by the community is binthe biluhuta. Binthe biluhuta is made of corn, which is boiled for several minutes, with the addition of lime inside. Lime serves to accelerate the cooking of corn kernels. During the cooking and soaking process, the reaction that occurs in traditional nixtamalization is the hydrolysis of the pericarp to arabinoxylans where the starch contained in the endosperm undergoes partial gelatinization and the annealing process simultaneously. Some fat will be saponified and the protein depolymerizes and dissolves (Guzman et al (2011) in Santiago-Ramos et al (2018b). This process was called nixtamalization. However, this process is not employed in the manufacture of grits.

Therefore, this study carries out the development of corn grains, which are rich in calcium by using corn grits that have undergone a process of nixtamalization. RojasMolina et al. (2009) and Rosado et al. (2005) argue that the absorption of calcium in corn tortillas is very high and depends on the amount of lime added. The addition of lime during the boiling process and steeping can increase calcium concentration and total absorption of calcium in corn tortilla products. During the nixtamalization, the corn grains go through different processes: thermo-alkaline (cooking), thermo-mechanical (wet milling), and again a thermal process during the baking. In each process, the corn components go through physicochemical changes that modify the final properties of the nixtamal, masa, and the tortilla. In the case of starch, in the presence of water as a 
solvent, the masa suffers at least three different gelatinization changes.

Martin (1985) explains that the main function of calcium is for the formation of bones and teeth. Calcium needs must be met from food intake because calcium in food is absorbed in the small intestine by an active transport process. Based on the above description, it is necessary to research the effect of lime concentration, and the duration of boiling of the proximate content, and calcium grits nixtamal corn as a raw material of Gorontalo traditional meal. Thus, the effect of lime concentration and the boiling process on the proximate and calcium content in corn grits is observed in this study.

\section{MATERIALS AND METHODS}

\section{Materials}

The main ingredients used to make a traditional meal in this study were nixtamalized corn meal from local varieties (motoro kiki) and commercial lime $(\mathrm{Ca}(\mathrm{OH}) 2)$ ). The variety is a new variety released by Gorontalo Province, Indonesia as a purified variety of local genetic from local resources and releases it as a non-hybrid variety (Varietas Bersari Bebas-VBB) (Puslitbang Tanaman Pangan 2009). The commercial lime is obtained from traditional markets commonly used by Gorontalo people that are known as whiting.

\section{Production of traditional meal from nixtamalize corn grits (Salazar et al. 2014)}

Traditional corn meal was made with elaboration method by Salazar et al. (2014). This method consisted of six steps: Boiling process, washing, drying, milling, and screening. In the boiling processed, water that used to boil was added by lime with each concentration consisting of $0.5 \%, 1 \%$, and $1.5 \%$ with the length of variation of boiling time consisting of 30 and 60 minutes. After sifting with 60 mesh sieve, grits of corn were ready to make a traditional meal. The complete step for nixtamalization process which based on Villada et al. (2017) with slight modification. The sample was prepared by cooking $500 \mathrm{~g}$ of traditional cornmeal in a solution of $1,5 \mathrm{~L}$ of distilled water and $2,5,5$ and $7,5 \mathrm{~g}$ of calcium hydroxide $(0.5,1$ and $1.5 \%, \mathrm{w} / \mathrm{w})$ for each treatment. The corn kernels were added to the container and heated until they reached $92^{\circ} \mathrm{C}$ for 30 and 60 minutes. After cooking, the maize was steeped for 24 hours. The nejayote was drained off. It is well known that during the nixtamalization process parts of corn kernels such as pericarp, germ, and endosperm fractions are lost to the cooking liquor that is called nejayote, and the excess of calcium is also deposited within this liquor. The nixtamal sample was rinsed twice with water. After rinsing, nixtamal corn (cooked grains in alkaline solution) was dehydrated at the ambient temperature until it dries. Furthermore, it was wet milled and passing through the screen with 60 mesh to converted into grits.

\section{Procedures}

Nurhayati (1994) states that during the process of boiling or processing, foodstuffs are affected in many ways including changes in carbohydrates that can cause both positive and negative changes in the quality and nutritional status.

\section{Method of analysis}

This research employed Randomized Complete Random Design (CRD) with two treatment factors: Factor I is the concentration of addition of lime (A) consisting of 3 levels: $0.5 \%, 1 \%, 1.5 \%$. Factor II is boiling duration (B) consisting of 2 levels: Boiling for 60 and 30 minutes. Data analysis used a statistical test method of Analysis of Variance (ANOVA) by using Microsoft Excel 2013.

\section{Proximate determination (Ikya et al. 2013)}

The proximate analysis (protein, fat, ash, moisture, and crude fiber) of the fermented maize flour and the blends was determined by the official methods of AOAC 2012 (Ikya et al. 2013). Carbohydrate was determined by difference (100 - the sum of the content of protein, fat, ash and water).

\section{Calcium determination (Lawani et al. 2014)}

Determination of Calcium by titrimetry A $25.0 \mathrm{~mL}$ aliquot of each digest was pipetted into a beaker, and $1 \mathrm{M}$ $\mathrm{NaOH}$ solution was added to adjust the $\mathrm{pH}$ to $12-13$. Two drops of solochrome dark blue were then added and immediately titrated against a $0.01 \mathrm{M}$ EDTA solution to the blue end-point. For every determination and evaluation, a standard curve of the mass of calcium $(\mathrm{mg})$ versus the amount of EDTA (millimoles) was plotted.

\section{RESULTS AND DISCUSSION}

\section{Carbohydrate}

Carbohydrates are the primary source of calories, and some carbohydrate groups produce fiber that is useful for digestion and has an essential role in determining the characteristics of foodstuffs. Carbohydrate content contained in a food can be known by the method of calculation that is the difference. The result of carbohydrate of corn grits is presented in Figure 1.

Carbohydrate in figure 1 shows that the range of carbohydrate contents for all treatments performs nixtamalization that is $74.44-75.36 \%$. The difference in the time of boiling corn for 30 and 60 minutes at each lime concentration yields the different percentage of carbohydrates. The difference indicates that the time of boiling corn powder affects the starch component especially gelatinization process, where the starch granules are not soluble in cold water but expand in hot water. The development of starch granules is reversible, back and forth if it does not pass through the temperature of gelatinization but changes its granule structure when gelatinization temperature is reached. 
Generally, gelatinization of starch consists of three phases, namely: the first phase of water slowly and back and forth into granules. The second phase of the granules will expand rapidly at a temperature of $60-85^{\circ} \mathrm{C}$, and the third phase when temperatures continue to rise then the amylose molecules diffuses out of the granules as a result of the granules contain only amylopectin alone and form a gel. While the temperature in the process of boiling nixtamal corn, which is the temperature reached when boiling water and maintained according to the length of time in each treatment. This phase is the cause of differences in carbohydrate content of corn grits nixtamal. Corn with a long boiling time of 60 minutes has a longer duration of water absorption by starch granules. The starch granules will then pass through the gelatinization process, and when the granules have reached their water absorption capacity, the starch granules will break apart, and the starch component present in the corn pipe will exit to reduce the amount of carbohydrate content of the nixtamal corn grits. At the 30-minute boiling, the process of gelatinization of starch occurs shorter, and the number of broken starch granules is less so that the process of losing some components of carbohydrates is less. In the study of Tan et al. (2009), when the process of heating and starch expands, there is some starch that dissolves into the water to make the former water stew becomes cloudy and slightly thick.

Unlike the corn grits in control which has the lowest carbohydrate content of $73.43 \%$, this is influenced by the grits control maize not passing through the boiling stage in the nixtamalization process. Nurhayati (1994) states that during the process of boiling or processing, foodstuffs are affected in many ways including changes in carbohydrates that can cause both positive and negative changes in the quality and nutritional status.

In addition, according to Ocheme et al. (2010), another proximate component in the form of protein and fat also influences the value of carbohydrates obtained because the percentage of carbohydrates is calculated based on the analysis by difference.

ANOVA result shows Fvalue $<$ Ftable $(\alpha=5 \%)$, meaning that the treatment of lime concentration, the duration of boiling, and the interaction between both of them do not affect carbohydrate grits of nixtamal corn. This result follows the research conducted by Bello-Perez et al. (2014) revealing that the carbohydrate content of corn treated with nixtamalization from calcium carbonate (lime) is not significantly different from the traditional corn.

\section{Protein}

Contents of protein corn grits reveal that in the treatment of $0.5 \%$ lime concentration, with 30 minutes of boiling time yield the highest percentage of $9.4 \%$, and the lowest percentage of protein content is found in $1.5 \%$ of the 60-minute boiling time, i.e. $9.11 \%$; meanwhile, the protein content of grits control maize is equal to $9.41 \%$. ANOVA result showed Fvalue $<$ Ftable $(\alpha=5 \%)$. This means that the treatment of lime concentration, boiling time, and interaction of both do not affect the content of protein grits of nixtamalized corn. The result of proteins of corn grits is presented in Figure 2.

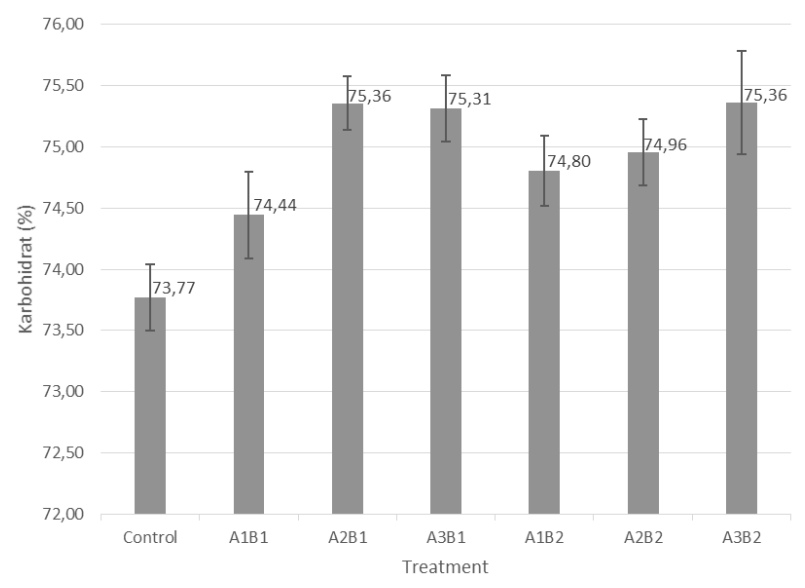

Figure 1. Carbohydrate percentage of corn grits. Controls: Without Treatment; A1B1: Lime of $0.5 \%$, boiling time of 60 minutes; A2B1: Lime 1\%, boiling time of 60 minutes; A3B1: Lime $1.5 \%$, boiling time 60 of minutes; A1B2: Lime of $0.5 \%$, boiling time of 30 minutes; A2B2: Lime $1 \%$, boiling time of 30 minutes; A3B2: Lime 1.5\%, boiling time of 30 minutes

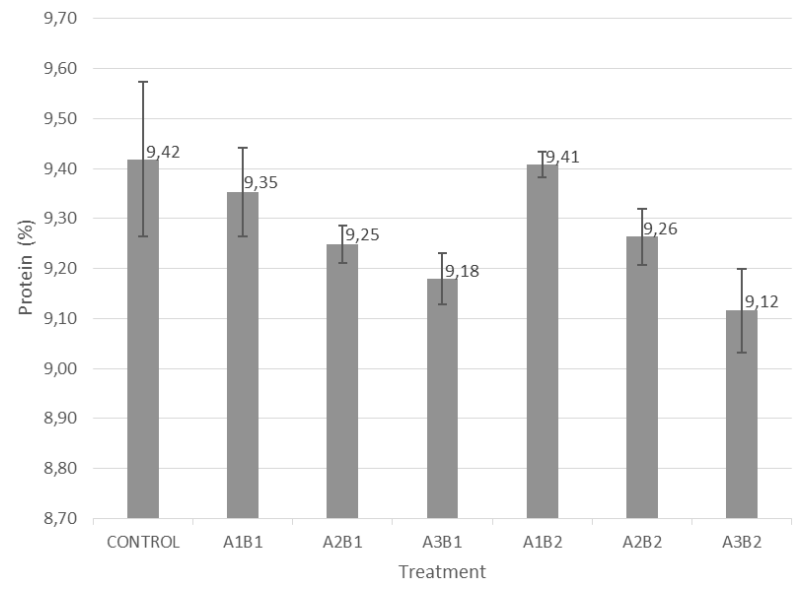

Figure 2. Protein percentage of corn grits. Controls: Without Treatment; A1B1: Lime of $0.5 \%$, boiling time of 60 minutes; A2B1: Lime 1\%, boiling time of 60 minutes; A3B1: Lime 1.5\%, boiling time of 60 minutes; A1B2: Lime of $0.5 \%$, boiling time of 30 minutes; A2B2: Lime 1\%, boiling time of 30 minutes; A3B2: Lime $1.5 \%$, boiling time of 30 minutes.

The low percentage of protein content is probably caused by the loss of some protein due to the release of the corn pericarp when soaked in the lime solution. Valderrama-Bravo et al. (2010) state that soaking treatment with an alkaline solution will cause high protein loss due to the release of the pericarp of maize. Therefore, the higher the concentration of lime so the protein grits of corn will decrease. The same thing also obtained from Chukwuma et al. (2016) research that The proteins in raw samples of corn were degraded and converted into soluble forms during boiling and this possibly led to the low amount of proteins in boiling quality protein maize (BQPM). It caused by the protein in corn is found in the endosperm, while the endosperm is protected by pericarp or the husk of corn 
husk. The chemical interaction of chalk and water in the boiling process is damage pericarp part. The longer the duration of boiling corn in the lime solution, the higher the protein content loss in the corn of nixtamal maize. The decrease in protein content in each boiling duration increases, due to the warming treatment that can cause the protein denatured, resulting in protein damage. On the other research, in addition, the loss of solids decreases from $3.2 \%$ to $12.0 \%$ in traditional nixtamal process to less than $1.5 \%$ in Ecological Nixtamal process; these solids include ashes, lipids, proteins, and dietary fiber (Ramos et al. 2018).

Research conducted by Tapotubun (2008) shows that the longer the heating time, the smaller the protein content. The decrease in protein content begins during the denaturation process. Denaturation process that occurs in damages to hydrogen bonds and other secondary forces that require protein molecules, or in other words, damage to secondary structures, tertiary and quartz protein molecules (Winarno 2004). If a protein is denatured, the typical threedimensional arrangement of the polypeptide chain is disrupted, and the molecule opens into a random structure, with no damage to the covalent skeleton structure.

Therefore, protein molecules are very fragile and immediately damaged by heat (Lehninger 2009). Furthermore, heat causes protein damage, and there is a decrease in protein content.

\section{Fat}

Lipids or fats have soluble properties in polar solvents such as ethanol, ether, chloroform, and benzene. ANOVA result reveals Fvalue $<$ Ftable $(\alpha=5 \%)$, meaning that there is no significant effect (F-count <F-table $\alpha$ 0.05) of treatment of lime concentration, boiling duration, and interaction between the content of fat grits of nixtamal corn. Analysis of the fat content of corn grits in this study can be seen in Figure 3. These results are similar to those reported by Vega Rojas et al. 2017, whereas the nixtamalization process does not cause significant changes in fatty acid components from germ oil.

Based on Figure 3, it can be seen that the lowest fat content is in the treatment of lime concentration of $1.5 \%$, with a boiling duration of 60 minutes, i.e., 3.36\%, while $0.5 \%$ lime concentration, with 30-minute boiling time has the highest fat content of $3.59 \%$ compared to controls and other treatments. For the fat content of grits, in controls had a fat content of $3.40 \%$ slightly higher than the $1.5 \%$ lime concentration treatment, with a boiling duration of $60 \mathrm{~min}$. The low-fat content of nitrogen in corn grits is due to the fatty nature of a foodstuff, which is sensitive to some conditions, one of which is the temperature. Based on the results obtained, it showed a decrease in average fat content occurred in the treatment with the duration of boiling is 60 minutes. This is due to the corn in the treatment, has a long period during boiling, so that the fat content in the material becomes damaged, due to heat obtained from boiling water, and the reaction between water and lime. Palupi et al. (2007) argue that the rate of fat damage varies with the temperature used and the processing time. The higher the temperature used, the fat damage will increase.
According to Tapotubun (2008), temperature and heating time affects the fat content of the product; it is closely related to the fatty nature of the solid at room temperature, while the temperature reached in boiling is $100^{\circ} \mathrm{C}$. Therefore, the fat will be melted and disappear with water. Treatment affects the content of corn fat; this is due to the nature of fat that is not heat resistant.

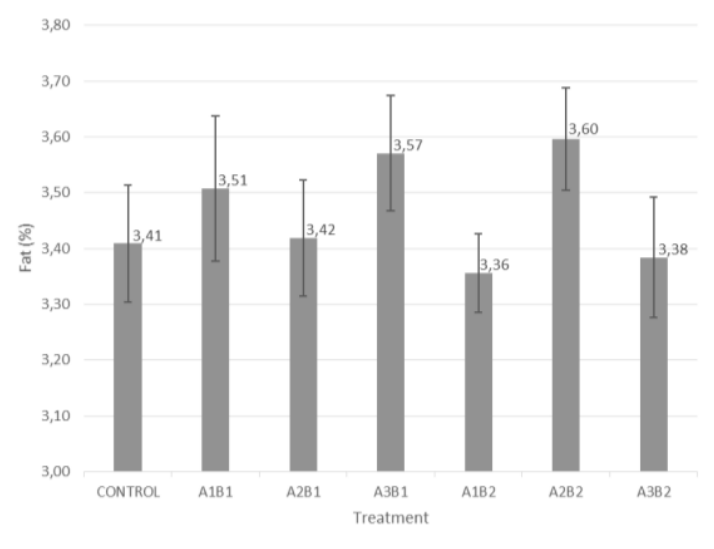

Figure 3. Fat Percentage of corn grits. Controls: Without Treatment; A1B1: Lime of $0.5 \%$, boiling time of 60 minutes; A2B1: Lime 1\%, boiling time of 60 minutes; A3B1: Lime 1.5\%, boiling time of 60 minutes; A1B2: Lime of $0.5 \%$, boiling time of 30 minutes; A2B2: Lime 1\%, boiling time of 30 minutes; A3B2: Lime $1.5 \%$, boiling time of 30 minutes

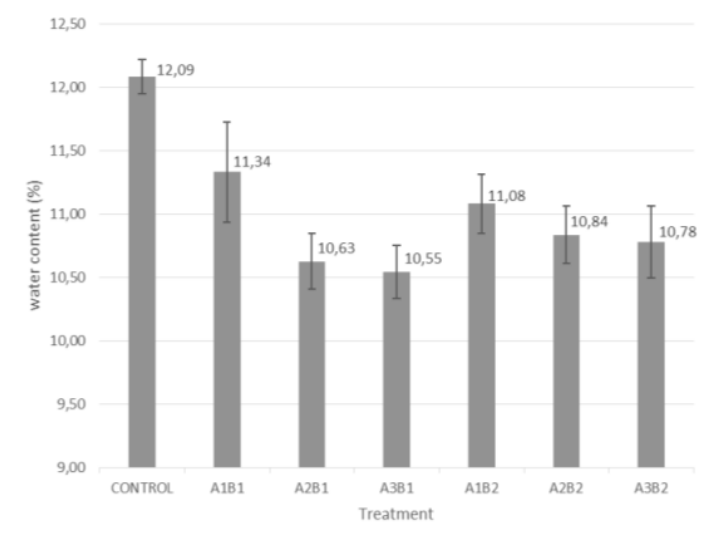

Figure 4. Water content percentage of corn grits. Controls: Without Treatment; A1B1: Lime of $0.5 \%$, boiling time 60 of minutes; A2B1: Lime 1\%, boiling time of 60 minutes; A3B1: Lime $1.5 \%$, boiling time of 60 minutes; A1B2: Lime of $0.5 \%$, boiling time of 30 minutes; A2B2: Lime $1 \%$, boiling time of 30 minutes; A3B2: Lime $1.5 \%$, boiling time of 30 minutes

\section{Water content}

Its moisture content strongly influences the stability of the quality of food during storage. The high water content in food will provide an opportunity for the growth of microorganisms and activate enzymes that can cause damage to the material. The water content of corn grits can be seen in Figure 4.

Based on Figure 4, the value of the water content of corn grits at all treatments ranges from $10.54 \%$ to $11.33 \%$. The lowest percentage value of the water content is at $1.5 \%$ 
lime concentration treatment, with a 30-minute boiling time, and the highest percentage of moisture content is in the treatment of $0.5 \%$ lime concentration, with a boiling time of 60 minutes. However, grits control maize has a water content of $12.08 \%$. This is due to grits of control maize not passing through the stages of the nixtamalization process.

In contrast, the water content of nixtamalization corn which shows the value of water content tends to decrease along with the amount of lime concentration added. This is caused by the ability of water catchment that is lower because of the solution $\mathrm{PH}$ is formed further away from the optimal $\mathrm{pH}$. For that reason, it affects the moisture content of corn. According to Upreti and Metzger (2006), the higher the calcium content formed, the smaller the amount of water that can be trapped. ANOVA result shows Fvalue $<$ Ftable $(\alpha=5 \%)$, meaning that the treatment of lime concentration, the duration of boiling, and the interaction between the two treatments are not significantly different. This is indicated by the value of factor A (lime concentration) $0.00014<3.88$ means that (F-count $<$ F-table $\alpha 0.05)$. Factor $\mathrm{B}$ (boiling time) $0.0006<4.75$ means that (F-count $<$ F-table $\alpha 0.05$ ), and interaction factor A with B has a value of $0.0000004<3.88$ which means that (F-count $<$ F-table $\alpha$ 0.05).

Another factor influencing the high and low water content grits nixtamal corn is the length of time boiling against corn. This is because when the boiling process takes place, corn on 60 minutes longer treatment interacts with boiling water compared to corn in the old treatment of 30 minutes of boiling time. This is related to the ability of the components of the composition of corn to absorb water, namely carbohydrates.

\section{Ash content}

Ash content can show total minerals in food. According to Winarno (2004), most foodstuffs which are about $96 \%$ consists of organic and water. The rest consists of mineral elements. Mineral elements are also known as organic substances or ash content. Here are the data of the test results of the ash content of corn grits.

Data in Figure 5 indicates the average grits of corn grits value of all treatments ranged from $1.34 \%$ to $1.39 \%$. Ash grits of corn grits have increased along with the amount of lime concentration added. On the other hand, the value of ash content obtained grits corn control is $1.31 \%$. This implies that the ash content of grits control corn is the lowest ash content compared with all treatments.

Addition of mineral elements of whiting in each treatment causes an increased ash content of nixtamalization corn grits. Sediaoetama (2006) finds out that food processing will decrease mineral content because minerals contained in foodstuffs will be damaged in most processing processes caused by $\mathrm{pH}$, oxygen, rays, and heat or a combination thereof. Meanwhile, according to Santoso et al. (2006), minerals in food can change the ANOVA result of Fvalue $<$ Ftable $(\alpha=5 \%)$ that shows that there is no significant difference (F-count $<$ F-table $\alpha 0.05)$ from lime concentration, boiling time, and combination of treatment to ash content of nixtamalization corn grits. Siregar (1998) also states that in the absorption system in the fruit, there are several contributing factors, among others, temperature, $\mathrm{pH}$, and cuticle fruits that significantly affect the absorption rate of $\mathrm{Ca}$ ions by the fruit. Some of the processing does give a decrease to ash content after steaming and boiling, but there is an increase of ash content after boiling with lime addition due to the reactive and water-soluble nature of the lime. Consequently, it seeps into the ingredients at the time of boiling, and the mineral content or ash will increase.

\section{The effect of lime concentration and boiling time on calcium grits content of nixtamal maize}

Nixtamalization is one of the processes that make some food have calcium content. Determination of calcium components in corn grits was carried out based on the standard curve shown in Figure 6. The results of the analysis of calcium content in corn grits are shown in Figure 7.

Figure 6 shows that the highest levels of calcium grits of corn nixtamal are obtained at a $1.5 \%$ lime concentration treatment, with the 30-minute boiling time of $1.09 \%$. The lowest calcium concentration obtained at lime concentration treatment at $1.5 \%$, with the 30 -minute boiling time that is equal to $1.01 \%$ is in contrast to the calcium in grits maize control rate of $1.02 \%$. For corn grits, the control of low levels of calcium is due to the grits of maize does not pass through the process of nixtamalization with various treatments. According to Mendez-Montealvo et al. (2006), nixtamalization process is a process of dipping corn pine in alkaline solution followed by cooking corn during a few hours.

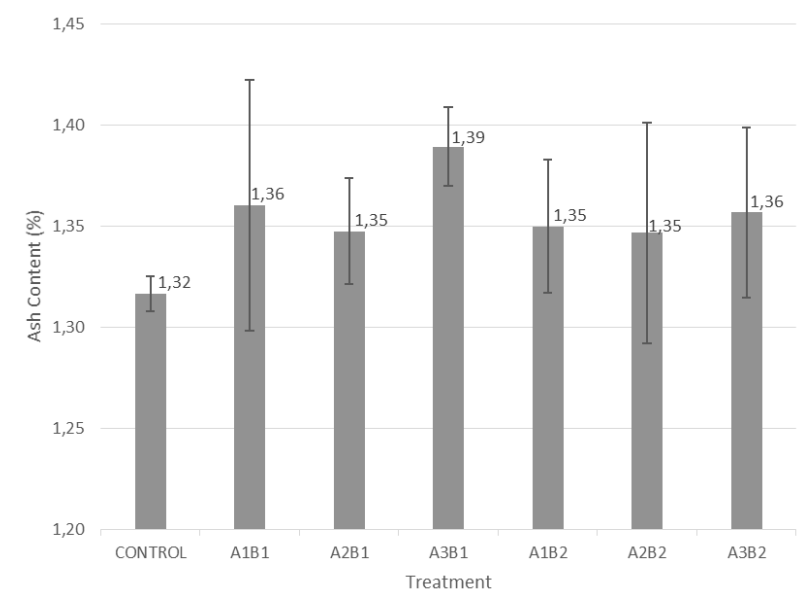

Figure 5. Ash content percentage of corn grits. Controls: Without Treatment; A1B1: Lime of $0.5 \%$, boiling time of 60 minutes; A2B1: Lime 1\%, boiling time of 60 minutes; A3B1: Lime 1.5\%, boiling time of 60 minutes; A1B2: Lime of $0.5 \%$, boiling time of 30 minutes; A2B2: Lime 1\%, boiling time of 30 minutes; A3B2: Lime $1.5 \%$, boiling time of 30 minutes 


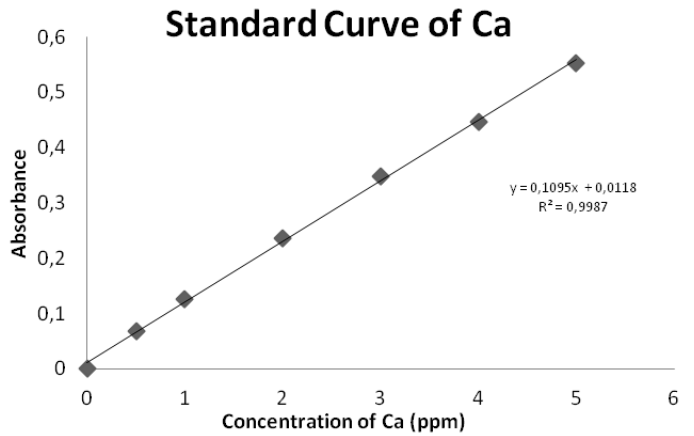

Figure 6. Standard curve of $\mathrm{Ca}$

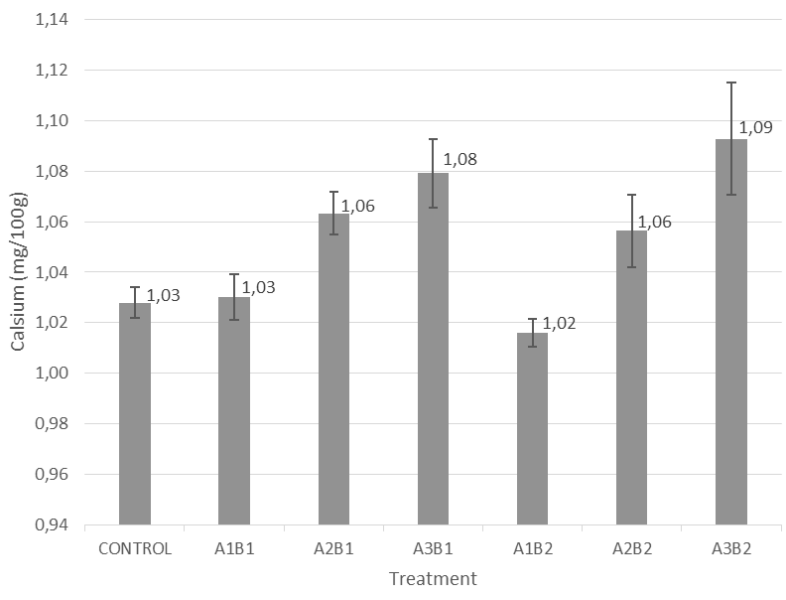

Figure 7. Calcium content percentage of corn grits. Control: Without Treatment; A1B1: Lime of $0.5 \%$, boiling time of 60 minutes; A2B1: Lime 1\%, boiling time of 60 minutes; A3B1: Lime $1.5 \%$, boiling time of 60 minutes; A1B2: Lime of $0.5 \%$, boiling time of 30 minutes; A2B2: Lime $1 \%$, boiling time of 30 minutes; A3B2: Lime $1.5 \%$, boiling time of 30 minutes

Nixtamalization is one of the basic modifications of starch because this process uses an alkaline solution. Based on Figure 6, it can be seen that the relationship between $\mathrm{Ca}$ concentration and $\mathrm{Ca}$ absorbance has a value of $\mathrm{R} 2=$ 0.9987 which means that the higher the lime concentration used, the more the absorbance of calcium content in corn of nixtamal corn will increase. The value of calcium grits of nixtamal maize in Figure 7 on each treatment increased with the increase of lime concentration in the process of nixtamalization, with the duration of boiling is 60 minutes and 30 minutes. High content of calcium, caused by lime solution added when boiling, have successfully entered with water into corn grits and trapped inside. Therefore, the content of calcium grits of corn is increasing.

Research conducted by Sediaoetoma (2006) concludes that the processing of food will reduce the mineral content because minerals contained in foodstuffs will be damaged in most processing caused by $\mathrm{pH}$, oxygen, light, and heat or a combination thereof. In contrast to Sediaoetoma (2006), particularly about the combination of material that can decrease the minerals contained in the food, this study finds out that there is a combination of lime concentration with the duration of boiling. Lime betel or $\mathrm{CaO}$ is a reactive material with water and will form $\mathrm{Ca}(\mathrm{OH})_{2}$ in the form of a water-soluble powder. The reaction of $\mathrm{CaO}$ with water is an exothermic reaction that releases heat energy (Chang and Tikkanen 1988, Galvan-Ruiz et al. 2007). With the heat energy released by the interaction of water and lime, it is expected to affect the rate of absorption of calcium and water into the inside of the fruit.

Meanwhile, boiling time can also affect the high content of calcium that successfully enter and trapped in the material. Siregar (1998) asserts that in the absorption system of the fruits, several factors influence it, such as temperature, $\mathrm{pH}$, and fruit cuticle that significantly affect the absorption rate of $\mathrm{Ca}$ ions by the fruit. The use of calcium hydroxide has so far been considered safe in a predetermined amount (Taylor, 1980).

The results of the analysis of variance show that the lime concentration, boiling duration, and interaction between the two are not significant (F-count $<$ F-table $\alpha$ $0.05)$ to the content of calcium grits of nixtamal maize. This is reinforced by the mean values obtained in Figure 7 showing that each treatment has no significant difference in calcium content. Seen in each of the factors that the lime and boiling time have almost the same effect, due to the concentration, temperature, and duration of boiling, each contributing to the high and low calcium content of a material. The higher the lime concentration given and the immersion time, the calcium content also produced increases. The same thing also obtained from Vega Rojas et al. (2017) in which the $\mathrm{Ca}^{++}$content increases if the $\mathrm{Ca}$ $(\mathrm{OH})_{2}$ content increases as well as the steeping time. This increase is related to the calcium ions diffusion into the internal structures of the germ and the accumulation of $\mathrm{CaCO}_{3}$.

In conclusion, nixtamalization process can reduce the moisture content of grits after drying in which ranging from 12.09 (control) to $10.55 \%$ The ash content of grits nixtamal increase from control $(1.32 \%)$ to highest ash content at A3B1 $(1.39 \%)$. The content of protein grits of corn nixtamal ranged from $9.1-9.40 \%$. The content of fat grits of corn nixtamal ranged from $3.36 \%$ to $3.59 \%$. Carbohydrate content of corn grits nixtamal ranged between $74.44-75.36 \%$. Nixtamalization process can increase the calcium content of grits nixtamal in which from $1.03 \%$ (control) to $1.09 \%$ although it is not significant. The best calcium content is at $1.5 \%$ lime concentration treatment with a 30-minute boiling time. Boiling time and concentration level of lime can affect the calcium content of grits nixtamal except for $0.5 \%$ both at 30 minutes and 60 minutes of boiling time.

\section{ACKNOWLEDGEMENTS}

We would like to thank the Indonesian Ministry of Education and Directorate General of Higher Education that have funded this research through the Competitive Research Grants Program and help the accomplishment of this research, as well as the Research Institute of Universitas Negeri Gorontalo, Indonesia for the assistance in this study. 


\section{REFERENCES}

Bello-Perez LA, Pamela C, Flores-Silva, Agama-Acevedo E, Juan de DF, Jose AL, Osvaldo HC. 2014. Effect of the nixtamalization with calcium carbonate on the indigestible carbohydrate content and starch digestibility of corn tortilla. J Cereal Sci DOI 10.1016/j.jcs.2014.05.001

Bressani, R., 2009. Chemistry, technology, and nutritive value of maize tortillas. Food Rev Intl 505 (6): 225-264. DOI: 10.1080/87559129009540868

Chang R, Tikkanen W. 1988. The Top Fifty Industrial Chemicals. Random House. New York, USA.

Chukwuma O.E., Olanipekun O.T., Udouso V.B., 2016. Effect of the Traditional Cooking Methods (Boiling and Roasting) on the Nutritional Profile of Quality Protein Maize. J Food Nutr Sci 4 (2): 34-40. DOI: 10.11648/j.jfns.20160402.12.

Galvan-Ruiz M, Baños L, Rodriguez-Garcia ME. 2007. Lime characterization as a food additive. Sens Instr Food Qual Saf 1 (4): 169-175.

Ikya JK. 2013. Proximate composition, nutritive and sensory properties of fermented maize, and full-fat soy flour blends for "agidi" production. Afr J Food Sci 7 (12): 446-450. DOI: 10.5897/AJFS09.224

Lawani SA, Abdur-rahin AG, Isah AB, Erasmus OO. 2014. Titrimetric determination of calcium content of some staple foodstuffs in NorthCentral Nigeria. J Food Sci Qual Manag 28: 50-58.

Lehninger A. 2009. Dasar-Dasar Biokimia Jilid I [Basics of Biochemistry Of Volume 1]. Erlangga. Jakarta, Indonesia.

Martin WD. 1985. Water and mineral. In: Harper's review of Biochemistry. 20 ed. Lange Medical Publication. Stamford, USA

Mendez-Montealvo G, Sanchez-Rivera MM, Paredes LO, Bello-Perez LA. 2006. Thermal and rheological properties of nixtamalized maize starch. Intl J Biol Macromol 15;40 (1): 59-63. DOI: 10.1016/j.ijbiomav.2006.05.009

Nurhayati T. 1994. Pengaruh Asam dan Bleaching terhadap Mutu Tepung Ikan [The Influence of Acid and bleaching towards Fish Flour Quality]. [Hon. Thesis]. Institut Pertanian Bogor, Bogor. [Indonesian].

Ocheme BOcheme, Oloyede OO, Mikailu EG. 2010. Effect of lime soaking and cooking (nixtamalization) on the proximate, functional and some anti-nutritional properties of millet flour. AU J.T. 14 (2) $131-138$

Palupi NS, Zakaria F R, Prangdimurti E. 2007. Pengaruh Pengolahan terhadap Nilai Gizi Pangan [The Effect of Processing on Food Nutritional Value]. Department of Food Science and Technology, IPB. Bogor, Indonesia.

Puslitbang Tanaman Pangan. 2009. Deskripsi varietas unggul palawija 1918-2009. Puslitbang Tanaman Pangan, Bogor. [Indonesian]

Ramos SD, Juan de DF, Cárdenasb, Véles-Medina JJ, Salazar R. 2018 Physicochemical properties of nixtamalized black bean (Phaseolus vulgaris L.) flours. J Food Chem 240: 456-462. DOI: 10.1016/j.foodchem.2017.07.156

Rojas-Molina, Gutiérrez E, Rojas A, Cortés-Álvarez M, Campos-Solís L. 2009. Effect of temperature and steeping time on calcium and phosphorus content in nixtamalized corn flours obtained by traditional nixtamalization process. Cereal Chem 86 (5): 516-521.
Rosado JL, Diaz M, Rosas A, Grifft I, Garcia OP. 2005. Calcium absorption from corn tortilla is relatively high and is dependent upon calcium content and liming in Mexican women. J Nutr 135: 25782581

Salazar R, Arámbula-Villa G, Luna-Bárcenas G, Figueroa-Cárdenas JD, Vázquez-Landaverde PA, Azuara E. 2014. Effect of added calcium hydroxide during corn nixtamalization on acrylamide content in tortilla chips. LWT- J Food Sci Tech 56: 87-92. DOI: 10.1016/j.lwt.2013.10.046

Santiago-Ramos D, Juan de Dios Figueroa-Cárdenas, José Juan VélesMedinab. 2018b. Viscoelastic behaviour of masa from corn flours obtained by nixtamalization with different calcium sources. J Food Chem 248: 21-28. DOI: 10.1016/j.foodchem.2017.12.041.

Santiago-Ramos D, Figueroa-Cárdenas JDD, Mariscal-Moreno RM, Escalante-Aburto A, Ponce-García N, Véles-Medina JJ. 2018a. Physical and chemical changes undergone by pericarp and endosperm during corn nixtamalization-A review. J Cereal Sci. 81: 108-117. DOI: $10.1016 /$ j.jcs.2018.04.003

Santoso J, Satako G, Yumiko YS, Takeshi S. 2006. Mineral content of Indonesian seaweed solubility affected by basic cooking. J Food Sci Tech 12 (1): 59-66.

Sediaoetoma AD. 2006. Ilmu Gizi: Untuk Mahasiswa dan Profesi Jilid I [Nutritional Sciences: For Students and Profession, Volume 1]. Dian Rakyat. Jakarta. [Indonesian]

Siregar F. 1998. Pengaruh Konsentrasi Natrium Benzoat dan Lama Penyimpanan Terhadap Mutu Manisan Buah Mangga Udang [The Effect of Natrium Benzoat Concentration and Storage Duration on Candied Mangga Udang]. [Hon. Thesis]. Universitas Sumatera Utara, Medan. [Indonesian]

Tan HZ, Tan LB. 2009. Starch noodles: History, classification, materials, processing, structure, nutrition, quality evaluating and improving. J Food Res Intl 42: 551-576.

Tapotubun AM. 2008. Efek Waktu Pemanasan Terhadap Mutu Presto Beberapa Jenis Ikan [The Effect of Heating Time on Presto of Several Fishes Quality]. Department of Fish Product Technology, Faculty of Fisheries and Marine Sciences, Universitas Pattimura. Ambon, Indonesia.

Taylor RJ. 1980. Food Additives. John Willey and Sons Ltd., Chichester, UK.

Upreti P, Metzger LE. 2006. Influence of calcium and phosphorus, lactose, and salt to moisture ratio on cheddar cheese quality: Manufacture and composition. J Dairy Sci 89: 420-428.

Valderrama-Bravo C, Rojas-Molina A, Gutiérrez-Cortez E, Rojas-Molina I, Oaxaca-Luna A, Rosa-Rincón ED, Rodríguez-García ME. 2010. Mechanism of calcium uptake in corn kernels during the traditional nixtamalization process: Diffusion, accumulation, and percolation. $\mathbf{J}$ Food Eng 98: 126-132. DOI: 10.1016/j.jfoodeng.2009.12.018.

Vega Rojas LJ, Rojas-Molina I, Gutiérrez Cortez E, Rincón Londoño N, Acosta Osorio A.A, Del Real López A. Rodríguez García M.E. 2017. Physicochemical properties of nixtamalized corn flour with and without germ. J Food Chem 220: 490-497. DOI: 10.1016/j.foodchem.2016.10.039.

Winarno FG. 2004. Kimia Pangan Dan Gizi [Food and Nutrition Chemistry]. Gramedia Pustaka Utama. Jakarta. [Indonesian] 